\title{
EVALUASI SISTEM DAN PROSEDUR UANG PERSEDIAAN (UP) PADA DINAS LINGKUNGAN HIDUP DAERAH PROVINSI SULAWESI UTARA
}

\author{
Fita Helena Pasuhuk ${ }^{1}$, Lintje Kalangi ${ }^{2}$, Jessy D.L. Warongan ${ }^{3}$ \\ ${ }^{1,2,3}$ Jurusan Akuntansi, Fakultas Ekonomi dan Bisnis, Universitas Sam Ratulangi, Jln. Kampus Bahu, manado \\ 191115, Indonesia \\ E-mail : fitapasuhuk@gmail.com
}

\begin{abstract}
Local Environment Agency North Sulawesi Province is an organization of local government to improve the welfare of the community, especially in environmental development. DLHD can not be separated from a Regional Device Organization (OPD) which will also finance office operations. This study aims to evaluate the procedure of inventory money in accordance with Permendagri No. 13 of 2006 at the Regional Environment Agency of North Sulawesi Province. The method of analysis used in this research is descriptive method. The result of the research shows that the system and procedures for applying of inventory money have not been in accordance with Permendagri. 13 of 2006 on the management of local finance, this is because there are still some procedures and documents - documents that are not suitable and not attached. preferably in the implementation of procedures and documents used in accordance with applicable regulations of Permendagri No. 13 of 2006, as a form of compliance and compliance with prevailing regulations and improving the duties and responsibilities in the system and procedures of money supply at the Regional Environment Agency of North Sulawesi Province.
\end{abstract}

Keywords: System and procedure, money supply, Permendagri No. 13 of 2006

\section{PENDAHULUAN}

Seiring dengan perkembangan pelayanan pemerintahan yang perlu dilakukan pemetaan dan penilaian dimulai dari visi, misi, tujuan dan program kerja organisasi, sekaligus beban kerja dan indikator kunci kinerja pejabat, serta petugas pelayanan publik, sehingga sistem dan pelayaan pemerintahan akan mengalami perubahan ke arah yang lebih baik, itu semua di dukung untuk mencapai pemerintahan yang baik (Good Governance.). Good Governance adalah suatu kewenangan untuk berbagai pengelolaan urusan negara baik secara politik, ekonomi dan administratif dalam pemerintahan. Demi terciptanya Good Governance maka pemerintah perlu menjalankan pelayanan publik yang solid, transparan dan akuntabilitas.

Dalam Permendagri No. 13 tahun 2006 dan perubahan keduanya Permendagri No. 21 tahun 2011 berisi tentang pedoman pengelolaan keuangan daerah, mengamanatkan bahwa Menteri Dalam Negeri melakukan pembinaan dan pengawasan pengelolaan keuangan daerah kepada pemerintah daerah antara lain pemberian dokumen sistem dan prosedur pengelolaan keuangan daerah. Dalam rangka pelaksanaan Permendagri tersebut, Menteri Dalam Negeri menerbitkan surat edaran nomor SE/900/316/BAKD yang berisi tentang pedoman sistem dan prosedur penatausahaan dan akuntansi, pelaporan dan pertanggujawaban keuangan daerah.

Sistem akuntansi pemerintahan daerah secara menyeluruh mencakup empat prosedur akuntansi yang terdiri dari, prosedur akuntansi penerimaan kas, pengeluran kas, selain kas, dan aset. Beberapa hal yang harus diperhatikan mengenai empat prosedur akuntansi tersebut yaitu, fungsi yang terkait, dokumen yang digunakan, laporan yang dihasilkan dan uraian teknis prosedur. Sistem dan prosedur akuntansi pengeluran kas terdiri dari dari empat sub sistem yaitu sub sistem akuntansi pengeluaran kas uang persediaan (UP), sub sistem akuntansi pengeluaran kas ganti uang (GU), Sub sistem akuntansi pengeluaran kas tambahan 
uang persediaan (TUP), sub sistem akuntansi pengeluaran kas langsung (LS). Setiap lembaga pemerintahan daerah tidak lepas dengan adanya belanja Organisasi Perangkat Daerah (OPD). Belanja OPD merupakan semua pengeluaran yang dipergunakan untuk membiayai kegiatan-kegiatan operasional kantor sehari-hari. Dalam melakukan transaksi belanja OPD diperlukan adanya uang persediaan yang diberikan kepada bendahara pengeluaran dalam melakukan pembiayaan-pembiayaan tersebut.

\section{TINJAUAN PUSTAKA}

\subsection{Konsep Akuntansi}

\subsubsection{Pengertian Akuntansi}

Menurut (Suardjono, 2015:7) akuntansi berasal dari kata bahasa inggris to account yang berarti perhitungan atau mempertanggungjawabkan. Kata akuntansi sendiri pada hakikatnya diambil dari kata accountancy yang berarti hal-hal yang bersangkutan dengan accountant (akuntan), yang bersangkutan dengan hal-hal yang dikerjakan oleh akuntan dalam menjalankan profesinya.

\subsubsection{Prinsip Akuntansi}

Menurut Ajeng (2014:17) Ada empat prinsip dasar akuntansi, yaitu sebagai berikut:

1. Pengukuran

Pengukuran yang dipergunakan dalam akuntansi adalah biaya historis (historical cost) dan fair value.

a. Historical cost: Perusahaan melaporkan aset dan kewajibannya berdasarkan nilai akuisisi atau biaya historis. Hal ini dilakukan untuk memenuhi karakteristik reliabel.

b. Fair value: Nilai sejumlah uang yang akan diterima dari penjualan aset atau transfer kewajiban yang didasarkan pada nilai pasar yang ada (masa kini) dan nilai pengukuran (nilai buku).

2. Pengakuan pendapatan

Pendapatan diakui saat terealisasi atau terjadi dan dihasilkan (pendapatan diterima secara tunai).

3. Pengakuan beban

Beban diakui saat pendapatan telah diterima atau dengan kata lain beban mengikuti pendapatan. Saat dilakukan pembayaran, beban tidak diakui. Namun, jika telah menghasilkan pendapatan, beban akan diakui.

4. Full disclosure

Laporan keuangan disajikan untuk memberikan putusan atas investasi seseorang atau kebutuhan pihak-pihak terkait sehingga laporan keuangan perlu menyampaikan informasi yang lengkap serta mampu mewadahi kebutuhan semua pihak yang berkepentingan.

\subsubsection{Standar Akuntansi}

Standar Akuntansi adalah suatu pedoman dalam penyusunan pelaporan keuangan. Di Indonesia badan yang berwenang untuk membentuk standar akuntansi adalah Dewan Standar Akuntansi yang berada dibawah Ikatan Akuntansi Indonesia (IAI) sebagai organisasi profesi akuntan.

\subsubsection{Bidang-Bidang Akuntansi}

Kebutuhan informasi keuangan yang semakin berkembang dengan baik dari segi jenis maupun jumlahnya, menuntut adanya perkembangan di bagian informasi keuangan tersebut secara cepat dan akurat. Spesialis akuntansi terbagi dalam bidang-bidang akuntansi, diantaranya :

1. Akuntansi keuangan ( financialAccounting);

2. Akuntansi manajemen (Management Accounting);

3. Akuntansi biaya (Cost Accounting);

4. Akuntansi perpajakan (Tax Accounting); 
5. Akuntansi anggaran (Budgetary Accounting);

6. Akuntansi pemeriksaan (Auditing);

7. Akuntansi pemerintahan (Governmental Accounting);

8. Akuntansi pendidikan (Education Accouting);

9. Akuntansi sistem (System Accounting);

10. Akuntansi international (International Accounting).

\subsection{Akuntansi Sektor Publik}

Akuntansi sektor publik dapat didefinisikan sebagai aktivitas jasa yang terdiri dari mencatat, mengklasifikasikan, dan melaporkan kejadian atau transaksi ekonomi, yang akhirnya akan menghasilkan suatu informasi keuangan yang akan dibutuhkan oleh pihakpihak tertentu, untuk pengambilan keputusan yang diterapkan pada pengelolaan dana publik di lembaga-lembaga tinggi Negara dan departemen-departemen dibawahnya. Wiratna, (2015:1).

\subsection{Standar Akuntansi Pemerintahan}

Standar akuntansi pemerintahan menurut Peraturan Pemerintah (PP) Nomor 71 tahun 2010 pasal 1 ayat 3, standar akuntansi pemerintahan adalah prinsip-prinsip akuntansi yang diterapkan dalam menyusunan dan menyajikan laporan keuangan pemerintahan.

\subsection{Sistem dan Prosedur Pembentukan dan Penggunaan UP}

Mahmud, dkk (2016) Uang persediaan merupakan sejumlah uang tunai yang disediakan untuk belanja operasional sehari-hari dari OPD yaitu untuk belanja barang dan jasa. Uang persediaan adalah istilah baru yang muncul dalam Permendagri No. 13 tahun 2006 yang kemudian direvisi menjadi Permendagri No. 21 tahun 2011 yang berisi tentang pedoman pengelolaan keuangan daerah. Uang persediaan merupakan sejumlah uang kas yang ada ditangan bendahara pengeluaran, dengan karakteristik sebagai berikut :

1. Hanya diberikan sekali untuk satu tahun anggaran;

2. Diberikan pada awal tahun anggaran;

3. Merupakan jumlah maksimal (pagu) uang yang dipegang oleh bendahara pengeluaran;

4. Untuk digunakan dalam pelaksanaan pembayaran berbagai kegiatan operasional kantor yang bersifat swakelola;

5. Bersifat revolving (adanya pengisian kembali jika telah terpakai);

6. Besarnya uang persediaan tergantung pada "kebijakan daerah" (biasanya dapat dinyatakan dalam Surat Keputusan Kepala Daerah).

\subsection{Sistem dan Prosedur Uang Persediaan menurut Permendagri No. 13 tahun 2006}

Permendagri No. 13 Tahun 2006 membahas mengenai sistem dan prosedur uang persediaan yang terdiri dari :

a. Penerbitan surat penyediaan dana

Setelah penetapan anggaran kas, PPKD dalam rangka manajemen kas menerbitkan SPD. Surat penyediaan dana yang sebagaimana dimaksud, disiapkan oleh kuasa BUD untuk ditandatangani oleh PPKD. Pengeluaran kas atas beban APBD dilakukan berdasarkan SPD atau dokumen lain yang dipersamakan dengan SPD.

b. Pengajuan surat permintaan pembayaran

Berdasarkan SPD atau dokumen lain yang dipersamakan dengan SPD sebagaimana dimaksud, bendahara pengeluaran mengajukan SPP kepada pengguna anggaran/kuasa pengguna anggaran melalui PPK-SKPD. Pengajuan dokumen SPP-UP yang dilakukan oleh bendahara pengeluaran untuk mendapatkan persetujuan dari pengguna anggaran/kuasa pengguna anggaran melalui PPK-SKPD dalam rangka pengisian uang persediaan.

c. Penerbitan surat perintah membayar

Dalam hal yang sebagaimana dimaksud, jika dokumen SPP-UP dinyatakan lengkap dan sah, pengguna anggaran/kuasa pengguna anggaran menerbitkan SPM. Dalam hal 
dokumen SPP yang sebagaimana dimaksud dinyatakan tidak lengkap atau tidak sah, pengguna anggaran/kuasa pengguna anggaran menolak menerbitkan SPM. Penerbitan SPM yang sebagaimana dimaksudkan paling lama 2 (dua) hari kerja terhitung pada saat diterimanya dokumen SPP.

d. Penerbitan surat perintah pencairan dana

Kuasa BUD memeriksa kelengkapan dokumen SPM yang diajukan oleh pengguna anggaran/kuasa pengguna anggaran agar pengeluaran yang diajukan tidak melampaui pagu dan memenuhi persyaratan yang ditetapkan dalam peraturan perundang-undangan. Dalam kelengkapan dokumen SPM-UP untuk penerbitan SP2D merupakan surat pernyataan tanggung jawab selaku pengguna anggaran/kuasa pengguna anggaran. Penerbitan SP2D sebagaimana yang telah dimaksudkan paling lama 2 (dua) hari kerja terhitung sejak diterimanya pengajuan SPM. Penolakan penerbitan SP2D sebagaimana yang dimaksud paling lama 1 (satu) hari kerja terhitung saat diterimanya pengajuan SPM. Kuasa BUD menyerahkan SP2D yang telah diterbitkan untuk keperluan uang persediaan/ganti uang persediaan/tambahan uang persediaan kepada pengguna anggaran/kuasa penggguna anggaran. Kuasa BUD menyerahkan SP2D yang diterbitkan untuk keperluan pembayaran secara langsung kepada pihak ketiga.

e. Penerbitan surat pertanggungjawaban

Bendahara pengeluaran serta administratif wajib mempertanggungjawabkan penggunaan uang persediaan/ganti uang persediaan/tambah uang persediaan kepada kepala SKPD melalui PPK-SKPD paling lambat tanggal 10 bulan berikutnya. Dokumen yang digunakan dalam menatausahakan pertanggungjawaban pengeluaran mencakup: a. register penerimaan laporan pertanggungjawaban pengeluaran, b. register pengesahan laporan pertanggungjawaban pengeluaran (SPJ), c. surat penolakan laporan pertanggungjawaban pengeluaran $(\mathrm{SP}), \quad$ d. register penolakan laporan pertanggungjawaban pengeluaran (SP), dan e. register penutupan kas.

\section{METODE PENELITIAN}

\subsection{Jenis Penelitian}

Jenis penelitian yang digunakan dalam penelitian ini adalah jenis penelitian yang bersifat Deskriptif. Penelitian deskriptif merupakan metode penelitian yang menggambarkan objek sesuai apa adanya dan akurat mengenai situasi atau kejadian sesuai dengan fakta-fakta serta membandingkan penerapan sistem dan prosedur uang persediaan dengan peraturanperaturan yang telah diterapkan pada DLHD Provinsi Sulawesi Utara.

\subsection{Tempat dan waktu Penelitian}

Penelitian ini laksanakan di Dinas Lingkungan Hidup Daerah Provinsi Sulawesi Utara yang bertempat di Jalan 17 Agustus No.7, Teling Atas, Wanea, Kota Manado, Sulawesi Utara. Waktu pelaksanaan penelitian tentang sistem dan prosedur uang persediaan dimulai pada bulan Maret 2018 sampai dengan bulan Juni 2018.

\subsection{Prosedur Penelitian}

Prosedur penelitian merupakan suatu langkah-langkah atau tahapan yang digunakan dalam sebuah penelitian. Adapun tahap-tahap penelitian yang digunakan yaitu:

1. Menetukan masalah penelitian, dalam tahap ini peneliti mengumpulkan sumber data berupa buku-buku atau jurnal yang berkaitan dengan permasalahan sistem dan prosedur uang persediaan.

2. Pengumpulan data, dalam tahap ini peneliti mulai mengumpulkan data dengan menggunakan metode wawancara, dokumentasi dan observasi.

3. Analisis data, dalam tahap ini peneliti menganalisis data mengenai sistem dan prosedur uang persediaan apakah sesuai dengan Permendagri No. 13 tahun 2006 dan akhirnya menarik kesimpulan serta memberikan saran. 


\subsection{Metode Pengumpulan Data}

\subsubsection{Jenis dan Sumber Data}

1. Jenis Data

Jenis data yang digunakan dalam penelitian ini dikelompokkan menjadi dua jenis (Sugiyono 2013:28), yaitu:

a. Data Kualitatif yang merupakan data berbentuk kata, kalimat, gerak tubuh, ekspresi wajah, bagan, gambar, dan foto.

b. Data Kuantitatif yaitu yang merupakan data yang berbentuk angka atau data kualitatif yang diangkakan (scoring).

Jenis data yang digunakan adalah data kualitatif yakni data yang disajikan secara deskriptif dalam bentuk uraian, seperti gambaran kantor, kegiatan operasional, serta data kepustakaan.

2. Sumber Data

Sumber data yang digunakan dalam penelitian ini dikelompokkan menjadi dua sumber (Sugiyono 2013:223), yaitu:

a. Data primer yang merupakan sumber data yang langsung memberikan data kepada pengumpul data.

b. Data Sekunder yang merupakan sumber data tidak langsung memberikan data kepada pengumpul data, misalnya hanya melalui dokumen.

Sumber data yang digunakan dalam penelitian ini adalah data primer, data yang diperoleh langsung dengan cara wawancara dari objek penelitian.

\subsection{Metode Analisis Data}

Metode analisis yang digunakan dalam penelitian ini adalah metode deskriptif. Metode deskriptif adalah sebuah metode yang digunakan untuk mendeskripsikan atau menggambarkan data yang telah terkumpul sebagaimana adanya tanpa bermaksud membuat kesimpulan yang berlaku untuk umum dan generalisasi. (Sugiyono, 2015 :147)

\section{HASIL ANALISIS DAN PEMBAHASAN}

\subsection{Gambaran Umum Dinas Lingkungan Hidup Daerah Provinsi Sulawesi Utara}

Institusi Lingkungan Hidup di Provinsi Sulawesi Utara terbentuk melalui Peraturan Daerah Nomor 10 Tahun 1997, dengan nomenklatur Badan Pengendalian Dampak Lingkungan Daerah (BAPEDALDA) Provinsi Sulawesi Utara, dan pada tahun 2003 melalui Peraturan Daerah Nomor 28 Tahun 2003 mengalami perubahan dengan nama Badan Pengelolaan Lingkungan Hidup (BPLH), dan di pimpin oleh seorang Kepala Badan yang berada di bawah dan bertanggung jawab kepada Gubernur melalui Sekretaris Daerah Provinsi Sulawesi Utara.

\subsection{Hasil Penelitian}

\subsubsection{Penerapan Sistem dan Prosedur Uang Persediaan}

Sistem dan prosedur uang persediaan pada Dinas Lingkungan Hidup Daerah (DLHD)

Provinsi Sulawesi Utara terdiri dari:

1. Penerbitan surat penyediaan dana

2. Pengajuan surat permintaan pembayaran

3. Penerbitan surat perintah membayar

4. Penerbitan surat perintah pencairan dana

5. Penerbitan surat pertanggungjawaban

Penerapan uang persediaan merupakan uang kas yang ada di tangan bendahara pengeluaran, hanya diberikan sekali untuk satu tahun anggaran dan diberikan pada awal tahun anggaran.yang merupakan jumlah maksimal (pagu) uang yang dipegang oleh 
bendahara pengeluaran, untuk digunakan dalam membantu pelaksanaan kegiatan operasional kantor.

\subsubsection{Penerbitan Surat Penyediaan Dana}

Diterbitkannya surat penyediaan dana, dalam hal ini dilakukan oleh bendahara pengeluaran Dinas Lingkungan Hidup Daerah Provinsi Sulawesi Utara. Pengguna anggaran menyerahkan SPD kepada Badan Pengelola Keuangan dan Aset Daerah. Berdasarkan SPD tersebut, BPKAD menyetujui permintaan sesuai dengan jumlah uang persediaan yang diminta.

\subsubsection{Pengajuan Surat Permintaan Pembayaran}

Penerbitan SPP dibuat oleh bendahara melalui aplikasi SIMDA keuangan. Penerbitan SPP anggaran sesuai dengan dokumen pelaksanaan anggaran (DPA), yaitu dari masingmasing bidang. Selanjutnya SPP ditandatangani oleh bendahara pengeluaran, selanjutnya dilampirkan dalam dokumen penerbitan SPM-UP.

\subsubsection{Penerbitan Surat Perintah Membayar}

Berdasarkan surat persetujuan atas surat penyediaan dana DLHD /kuasa pengguna anggaran menerbitkan SPM, setelah SPM-UP diterbitkan selanjutnya langsung ditanda tangani oleh Kepala Dinas Lingkungan Hidup Daerah Provinsi Sulawesi Utara dan diajukan ke BPKAD.

\subsubsection{Penerbitan Surat Perintah Pencairan Dana}

Surat perintah pencairan dana merupakan dokumen yang diterbitkan oleh BPKAD setelah BPKAD meneliti kelengkapan dokumen SPM yang diajukan oleh pengguna anggaran/kuasa pengguna anggaran. Prosedur penerbitan surat perintah pencairan dana yaitu:

1. Pengguna Anggaran menyerahkan SPM kepada Kuasa BPKAD.

2. BPKAD meneliti kelengkapan SPM yang diajukan.

3. Apabila SPM dinyatakan lengkap BPKAD menerbitkan SP2D paling lambat 2 hari kerja sejak diterimanya pengajuan SPM.

4. SP2D diserahkan kepada bank dan pengguna anggaran.

5. Kuasa BPKAD sendiri harus mencatat SP2D dan nota debet (dari bank) pada dokumen penatausahaan, yang terdiri dari buku kas penerimaan, buku kas pengeluaran.

6. Pengguna anggaran menyerahkan SP2D kepada bendahara pengeluaran.

\subsubsection{Penerbitan Surat Pertanggungjawaban}

Prosedur penerbitan surat pertanggungjawaban sebagai berikut:

1. Bidang-bidang DLHD Provinsi Sulawesi Utara mengajukan SPJ yang sudah memiliki perjanjian terlebih dahulu dengan toko,

2. Dimasukan ke bagian keuangan untuk diverifikasi dan tandatangan verifikasi, selanjutnya ditandatangani oleh PPTK bidang, sekretaris dinas, dan ditandatangani oleh kepala dinas selaku pengguna anggaran.

3. Jika SPJ dinyatakan lengkap, barulah anggaran yang diminta ditransfer ke rekening pihak ketiga (toko).

\subsection{Pembahasan}

\subsubsection{Penerapan Sistem dan Prosedur Uang Persediaan}

Berdasarkan Permendagri No. 13 tahun 2006 mengenai sistem dan prosedur uang persediaan, berawal dengan dilakukannya surat penyediaan dana yang dibuat oleh BUD/Kuasa BUD untuk penerbitan SPP. Dengan SPD yang telah diterima, bendahara pengeluaran mengajukan SPP. Jika dokumen SPP dinyatakan lengkap dan sah pengguna anggaran/kuasa pengguna anggaran menerbitkan SPM. Kuasa BUD meneliti kelengkapan dokumen SPM untuk menerbitkan SP2D. Kuasa BUD menyerahkan SP2D yang diterbitkan untuk keperluan uang persediaan kepada pengguna anggaran/kuasa pengguna anggaran, kuasa BUD menyerahkan SP2D yang diterbitkan untuk keperluan pembayaran langsung kepada pihak ketiga. 


\subsubsection{Penerbitan Surat Penyediaan Dana}

Penerbitan surat penyediaan dana pada DLHD yaitu, diterbitkannya SPD dalam yang dilakukan oleh bendahara pengeluaran DLHD Daerah, kemudian diberikan kepada pengguna anggaran untuk memberikan keterangan yang diperlukan dan mengarsipkan SPD yang diterima, selanjutnya pengguna anggaran menyerahkan SPD kepada Badan Pengelola Keuangan dan Aset Daerah (BPKAD). Berdasarkan SPD tersebut, BPKAD menyetujui permintaan dan mengeluarkan surat persetujuan dari BPKAD. Rancangan SPD DLHD Provinsi Sulawesi Utara secara sistem dan prosedur yang berlaku belum sesuai dengan prosedur yang digunakan dalam Permendagri No. 13 tahun 2006, karena penerbitan SPD seharusnya di lakukan PPKD dalam rangka manajemen kas dan disiapkan oleh BUD untuk di tandatangani oleh PPKD.

\subsubsection{Pengajuan Surat Permintaan Pembayaran}

Pelaksanaan pengajuan SPP pada DLHD yaitu, SPP dibuat oleh bagian keuangan melalui aplikasi SIMDA keuangan. Pengajuan SPP anggaran sesuai dengan DPA dari masing-masing bidang. Selanjutnya SPP ditandatangani oleh bendahara pengeluaran, dilampirkan dan diajukan secara bersamaan dengan SPM-UP ke BPKAD. Secara sistem dan prosedur yang berlaku menurut Permendagri No. 13 tahun 2006 belum sesuai karena pengajuan SPP hanya dilampirkan dalam SPM dan tanpa adanya pengajuan dokumen SPPUP.

\subsubsection{Penerbitan Surat Perintah Membayar}

Penerbitan SPM merupakan otoritas atau kewenangan dari pengguna anggaran atau kuasa pengguna anggaran, dimana SPM ditandatangani oleh pengguna anggaran atau kuasa pengguna anggaran. hal ini sebagai sebuah pernyataan penggunaan anggaran dilingkup OPD. SPM yang telah ditandatangani oleh pengguna anggaran atau kuasa pengguna anggaran kemudian diajukkan kepada BUD untuk sebagai dasar penerbitan SP2D. Adapun dokumendokumen dalam penerbitan SPM yaitu lembar SMP, lembar control, SPP, surat pernyataan tanggungjawab belanja yang ditandatangani oleh kepala dinas. Secara sistem dan prosedur yang berlaku sudah sesuai dengan prosedur yang digunakan dalam Permendagri No. 13 tahun 2006.

\subsubsection{Penerbitan Surat Perintah Pencairan Dana}

Dalam hal dokumen SPM dinyatakan lengkap, kuasa BUD menerbitkan SP2D. Kuasa BUD menyerahkan SP2D yang diterbitkan untuk keperluan uang persediaan kepada pengguna anggaran/kuasa pengguna anggaran..Surat perintah pencairan dana uang persediaan merupakan surat yang dipergunakan untuk mencairkan dana uang persediaan lewat bank. Dalam kegiatan ini Dinas Lingkungan Hidup Daerah Provinsi Sulawesi Utara telah melaksanakan penerbitan SP2D sesuai dengan ketentuan Permendagri No. 13 tahun 2006.

\subsubsection{Penerbitan Surat Pertanggungjawaban}

Bidang-bidang DLHD Provinsi Sulawesi Utara mengajukan surat pertanggungjawaban yang sudah memiliki perjanjian terlebih dahulu dengan toko dan dimasukan ke bagian keuangan untuk diverifikasi dan tandatangani verifikasi, selanjutnya ditandatangani oleh PPTK bidang, sekretaris dinas, dan ditandatangani oleh kepala dinas selaku pengguna anggaran. Prosedur pertanggungjawaban yang dilakukan oleh bendahara ini Dinas Lingkungan Hidup Daerah Provinsi Sulawesi Utara sudah sesuai dengan Permendagri No. 13 tahun 2006.

\section{KESIMPULAN DAN SARAN}

5.1. Kesimpulan

Berdasarkan hasil penelitian dan pembahasan yang dilakukan dalam mengevaluasi 
sistem dan prosedur uang persediaan pada Dinas Lingkungan Hidup Daerah Provinsi

Sulawesi Utara, maka dapat diambil kesimpulan sebagai berikut:

1. Sistem dan prosedur uang persediaan pada Dinas Lingkungan Hidup Daerah Provinsi Sulawesi Utara khususnya dalam prosedur penerbitan surat penyediaan, belum sesuai dengan ketentuan Permendagri No. 13 tahun 2006 tentang pengelolaan keuangan daerah, hal ini disebabkan karena penerbitan SPD seharusnya di lakukan PPKD dalam rangka manajemen kas dan disiapkan oleh BUD untuk di tandatangani oleh PPKD.

2. Sistem dan prosedur uang persediaan pada Dinas Lingkungan Hidup Daerah Provinsi Sulawesi Utara khususnya dalam prosedur pengajuan surat permintaan pembayaran belum sesuai dengan ketentuan Permendagri No. 13 tahun 2006 tentang pengelolaan keuangan daerah, hal ini disebabkan oleh tidak terpenuhinya prosedur pengajuan SPP yang hanya dilampirkan dalam SPM dan tanpa adanya pengajuan dokumen SPP-UP yang dipercayakan.

3. Sistem dan prosedur uang persediaan pada Dinas Lingkungan Hidup Daerah Provinsi Sulawesi Utara khususnya dalam prosedur penerbitan surat perintah membayar sudah sesuai dengan ketentuan Permendagri No. 13 tahun 2006 tentang pengelolaan keuangan daerah.

4. Sistem dan prosedur uang persediaan pada Dinas Lingkungan Hidup Daerah Provinsi Sulawesi Utara khususnya dalam prosedur penerbitan surat perintah pencairan dana sudah sesuai dengan Permendagri No. 13 tahun 2006 tentang pengelolaan keuangan daerah.

5. Sistem dan prosedur uang persediaan pada Dinas Lingkungan Hidup Daerah Provinsi Sulawesi Utara khususnya dalam prosedur penerbitan surat pertanggungjawaban sudah sesuai dengan Permendagri No. 13 tahun 2006 tentang pengelolaan keuangan daerah.

\subsection{Saran}

Saran yang diberikan berdasarkan penelitian dan pembahasan yang mungkin dapat dipertimbangkan sebagai masukan ada Dinas Lingkungan Hidup Daerah Provinsi Sulawesi Utara adalah:

1. Sebaiknya dalam pelaksanaan prosedur surat penyediaan dana, disesuaikan dengan peraturan yang berlaku yaitu Permendagri No. 13 tahun 2006 mengenai tugas dan tanggungjawab dalam penerbitan surat penyediaan dana.

2. Sebaiknya dalam pelaksanaan prosedur surat permintaan pembayaran, mengenai pengajuan surat permintaan pembayaran serta dokumen-dokumen yang digunakan di sesuaikan dengan peraturan yang berlaku yaitu Permendagri No. 13 tahun 2006, sebagai bentuk kepatuhan dan ketaatan terhadap peraturan yang berlaku.

3. Sebaiknya dalam prosedur surat perintah membayar serta dokumen-dokumen yang akan dilampirkan, lebih ditingkatkan dan diharapkan tetap mengikuti peraturan yang berlaku.

4. Sebaiknya dalam prosedur surat perintah pencairan dana dapat mempertahankan dan diharapkan untuk tetap mengikuti peraturan yang berlaku jika terjadi perubahan peraturan.

5. Sebaiknya dalam prosedur surat pertanggungjawaban dan disiplin pegawai dalam menjalankan tugas lebih ditingkatkan agar dalam proses prosedur surat pertanggungjawaban dapat berjalan sesuai dengan yang diharapkan.

\section{DAFTAR PUSTAKA}

Andrew M Saputra. 2013. Analisis Penerapan Sistem Dan Prosedur Pengeluaran Kas Pada BPBD Sulawesi Utara. Jurnal EMBA. Vol. 1. No. 3. Hal. 32-43.

Ajeng, W. 2014. Buku Saku Akuntansi. Laskar Raksara: Jakarta.

Bastian, Indra. 2013. Akuntansi Sektor Publik Suatu Pengantar Edisi Ketiga. Penerbit Erlangga: Jakarta. 
Dwi Fatimah. 2017. Analisis Sistem Pengeluaran Kas Pada Badan Pusat Statistik Kabupaten Sleman.

Dr. Julius Miroga 2015. An Evaluation Of The Internal Control System Of Cash In Management And Growth Of Small Business In Kenya : A Case Of Nairobi Small Business. International Journal Of Management And Economics Invention. Pages. 127145.

Febrian Singgima. 2016. Evaluasi Prosedur Pengeluaran Kas Belanja Langsung Pada Dinas Pendidikan Provinsi Sulawesi Utara. Universitas Sam Ratulangi. Jurnal EMBA. Vol. 4 No. 1. Hal 725.

Feri Prayitno. 2016. Evaluasi Penerapan Sistem Akuntansi Uang Persediaan Pada Dinas Pertanian Dan Peternakan Provinsi Sulawesi Utara. Jurnal EMBA. Vol.4 No.2. Diakses 21 April 2018. Hal 673-680.

Fretty S Tuerah. 2013. Evaluasi Pelaksanaan Sistem Dan Prosedur Penerimaan Dan Pengeluaran Kas Dinas Kependudukan Dan Pencatatan Sipil Minahasa Tenggara. Jurnal EMBA. Vol. 1 No. 3. Hal. 443-453

Sujarweni, Wiratna. 2015. Akuntansi Sektor Publik. Pustaka Baru Press, Yogyakarta.

Sugiyono. 2013. Metode Penelitian Kuantitatif Kualitatif Dan R \& D Bandung : Alfabeta.

Sugiyono. 2015. Metode Penelitian Pendidikan. Bandung: Alfabeta.

Suwardjono. 2015. Teori Akuntansi Perekayasan Laporan Keuangan. Edisi Ketiga. Yogyakarta. Bpfe.

Syaiful Bahri. 2016. Pengantar Akuntansi Berdasarkan Sak Etap Dan Ifrs. Jakarta: Andi.

Yurike. S.Pido. 2017. Evaluasi Sistem Dan Prosedur Pembentukan Serta Penggunaan Uang Persediaan Padakantor Bapelitbangda Kota Manado. Jurnal Riset Akuntansi Going Concern. 12 (2). Hal. 77-89. 